\title{
Cosmopolitanism and Competition: Probing the Limits of Egalitarian Justice
}

\section{David Wiens}

\begin{abstract}
This paper develops a novel competition criterion for evaluating institutional schemes. Roughly, this criterion says that one institutional scheme is normatively superior to another to the extent that the former would engender more widespread political competition than the latter. I show that this criterion should be endorsed by both global egalitarians and their statist rivals, as it follows from their common commitment to the moral equality of all persons. I illustrate the normative import of the competition criterion by exploring its potential implications for the scope of egalitarian principles of distributive justice. In particular, I highlight the challenges it raises for global egalitarians' efforts to justify extending the scope of egalitarian justice beyond the state.
\end{abstract}

Cosmopolitans assert that the scope of moral concern is global: given their common status as moral equals, all individual persons are owed equal respect and concern. Global egalitarians argue, in addition, that the scope of application for egalitarian principles of distributive justice must extend from the domestic to the global sphere. There are two primary routes to global egalitarianism, one principled, the other pragmatic. The first contends that, as a matter of normative justification, state borders are irrelevant for fixing the scope of egalitarian justice (e.g., Beitz, 1999; Caney, 2005; Moellendorf, 2002). The second contends that, with respect to practical implementation, states frustrate our attempts to satisfy the demands of cosmopolitanism; thus, they are not core components of a just institutional scheme (e.g., Cabrera, 2004; Macdonald, 2008; Pogge, 1992). ${ }^{1}$ A theory of global justice that takes states to restrict the scope of egalitarian distributive

\footnotetext{
Author's note. Earlier versions of this paper were presented at the Canadian Political Science Association annual meeting, the Centre for Applied Philosophy and Practical Ethics (ANU), the Monash Political Theory Workshop, the University of California, San Diego, and the University of Michigan. For helpful suggestions, thanks to those audiences, and to Elizabeth Anderson, Christian Barry, Corey Brettschneider, Tom Christiano, Bill Clark, Michael Goodhart, Jonathan Kuyper, Mika LaVaque-Manty, Seth Lazar, Peter Railton, and Leif Wenar. Thanks also to the Editor, Fabienne Peter, and two anonymous referees.

1 Although the two are compatible, neither claim implies the other. One can hold that egalitarian principles apply globally and that they can nonetheless be satisfied in a world of states. Or one can hold that, in principle, state borders limit the scope of egalitarian principles but that we should abolish them because they hinder our attempts to fulfill non-egalitarian cosmopolitan requirements (e.g., poverty eradication); in the absence of state borders, egalitarian principles apply globally.
} 


\section{David Wiens}

principles is at odds with moral cosmopolitanism. ${ }^{2}$

So say global egalitarians ("Extenders" for short). There are numerous theorists ("Restricters") who defend limits on the scope of egalitarian justice despite endorsing the basic cosmopolitan moral commitment. ${ }^{3}$ Two popular strategies are on offer to achieve this reconciliation. Principled Restricters argue that the features that ground egalitarian principles - e.g., political coercion (Blake, 2001; Miller, 2010), national affiliation (Miller, 2007), or social cooperation (Sangiovanni, 2007) — are manifest (to the required degree) only in states. Hence, as a matter of normative justification, states remain the locus of egalitarian duties of justice without denying moral cosmopolitanism. Pragmatic Restricters argue that, as a matter of practical implementation, states are an effective (perhaps necessary) means for satisfying the demands of cosmopolitanism. For instance, Goodin (1988) argues that a system of states helps us satisfy the demands of cosmopolitanism more efficiently and effectively by assigning responsibility for the care of particular persons to particular (local) agents. de Bres (2011) extends this by arguing that some goods that contribute to individuals' well-being are available only within the state. Ypi (2012) argues that states provide an important training ground for cultivating the virtues and motivational capacity required to realize cosmopolitanism.

Rather than navigate these disputes in detail, I probe an area of agreement. ${ }^{4}$ I show that Extenders' and Restricters' common commitment to moral cosmopolitanism implies a shared criterion for evaluating institutional schemes, which I call the competition criterion. Roughly, this criterion says that one institutional scheme is normatively superior to another to the extent that the former would engender greater political competition than

2 Crucially, I use "state" broadly to refer to sovereign subglobal political communities generally rather than to currently existing sovereign states in particular. I take this usage to be consistent with the existing global justice literature. More on this below.

3 A note on terminology. I depart from the convention of using "cosmopolitanism" and "global egalitarianism” more or less synonymously (see also Gilabert 2012; Risse 2012; cf. Ronzoni and Valentini forthcoming). This is because adherence to the core tenet of cosmopolitanism - viz., the moral equality of individuals and the general moral requirement to show individuals equal respect and concern (see, e.g., Pogge, 2008, ch. 1) - does not distinguish those who endorse the global scope of egalitarian principles from those who deny this (see, e.g., Blake, 2013; Sangiovanni, 2007). Put differently, much of the debate between global egalitarians and their so-called "statist" opponents is an intramural dispute among those who share basic cosmopolitan moral commitments. I emphasize this fundamental agreement by reserving the term "cosmopolitan" for those who share a commitment to what I've called the "core tenet of cosmopolitanism"; I use the terms "Extender" and "Restricter" for those who differ about the scope of egalitarian distributive principles (cf. Armstrong's 2014 distinction between "egalitarians" and "minimalists").

4 Ronzoni and Valentini (forthcoming) offer a more detailed survey of the disputed terrain, which is, in outline, consonant with the brief survey I give here. 
the latter (I state this more precisely in section 2). In section 1, I assume a commitment to moral cosmopolitanism and show that fulfilling this commitment requires, at a minimum, that all persons are able to live minimally decent and worthwhile lives. As a first step, realizing this outcome requires that every person lives within a political community that is able to achieve a minimum threshold of political and economic development. This leads to an investigation of the determinants of development outcomes, which I undertake in section 2. I argue that governing authorities are most likely to reliably advance persons' general interests in (inter alia) the rule of law, civil and political rights, and material well-being to the extent that their constituents are able to effectively circumscribe the government's use of political power and constrain it to advance their interests. Individuals are able to do so to the extent that political competition is manifest - that is, to the extent that political leaders must contend for the support of those they aspire to rule. In sum, broad political competition is a crucial causal factor for robust realization of a minimum level of political and economic development, which is, in turn, required to fulfill a commitment to moral cosmopolitanism. ${ }^{5}$

Having shown the competition criterion to be a shared criterion for evaluating institutional schemes, I begin to explore its potential implications for disputes regarding the scope of egalitarian principles of justice. I show that, in light of this criterion, settling the scope of egalitarian justice depends on numerous thorny empirical issues that both Extenders and Restricters have thus far neglected. Although the competition criterion raises questions for Extenders and Restricters alike, I focus my investigation by highlighting the challenges it poses for Extenders in particular.

I start (in section 3.1) by considering the ways in which the state serves to foster and protect the sort of competition required to bolster the likelihood of achieving a minimum level of development. This investigation raises the prospect that a system of states plays a pivotal role in realizing cosmopolitan objectives. I show that, to sustain their challenge to pragmatic restrictions on the scope of egalitarian justice, Extenders bear an as-yet unmet burden to show that the requisite political competition is fostered more effectively by global institutional alternatives to an international system of states.

Absent adequate reasons to abandon a system of states, I go on (in section 3.2) to consider the likely impact of cross-border redistributive transfers on the level of political competition within states. This investigation raises the prospect that states' significance as spheres of political competition make them relevant for determining the scope of

5 The competition in question need not be democratic in nature. What's important is that incumbent political leaders face credible challenges to their rule (perhaps only prospectively) and that they must solicit cooperation from citizens to sustain their rule. More on this in section 2. 
egalitarian justice. I show that, to sustain their challenge to principled restrictions on the scope of egalitarian justice, Extenders must show that the kinds of institutionalized transfer schemes required to satisfy the demands of egalitarian justice do not undermine the political competition required to fulfill a commitment to moral cosmopolitanism. ${ }^{6}$

Let me be clear about my ambitions. My main aim is to introduce a novel criterion for institutional evaluation and show that this criterion is implied by a commitment to moral cosmopolitanism - a commitment shared by Extenders and Restricters alike. Section 3 has two additional aims: to identify, in light of the competition criterion, the range of empirical issues on which debates about the scope of egalitarian principles turn; and to illustrate the normative significance of these issues by indicating the body of evidence Extenders must assemble to justify their position. None of this is meant to show that Extenders can't sustain their position; I mean to show that they have yet to meet the burden required to do so. ${ }^{7}$ This burden cannot be met by showing - as Extenders often have - that there are counterfactual worlds at which global egalitarian principles are given an effective institutional articulation; a mere possibility proof is not enough (cf. Wiens, 2013). The upshot of sections 2 and 3 is that Extenders can sustain their position only by providing credible institutional models for implementing global egalitarianism that can be effectively realized (perhaps only incrementally) given the ways in which political authority is organized and exercised in our world.

My argument implies that Extenders cannot sustain their position using standard Extender strategies for countering existing Restricter arguments. Debates between principled Extenders and Restricters typically center on questions about the grounds of egalitarian justice - whether duties of egalitarian justice are owed to others in virtue of common membership in an institutionalized scheme of political coercion or social cooperation or national affiliation, or whether such duties are owed to others simply in virtue of our

6 A worry arises here that states' significance as spheres of political competition poses a pragmatic rather than principled restriction on the scope of egalitarian justice, since the scope restriction ostensibly turns on a claim about the feasibility of certain kinds of institutional mechanisms for satisfying egalitarian duties, not on claims about the normative reasons we have to satisfy egalitarian duties in one domain or another. Although I will return to this issue briefly at the end of the paper, lengthy discussion of the underlying approach to normative justification is beyond the scope of this paper. This paper is an extended illustration rather than extended defense of the underlying approach. For now, this will have to suffice: A general principle articulating certain duties of justice is justified — we have sufficient reason to comply with its demands - only if it can be shown that there is an institutional scheme that could effectively satisfy the duties in question under feasible background conditions. See Knight and Johnson (2011); Wiens (2015) for extended defenses of this approach to normative justification.

7 Alternately, one might use the competition criterion to establish an analogous result against Restricters. I'm agnostic regarding the prospects for doing so successfully. 


\section{Cosmopolitanism and Competition}

shared humanity. As noted above, Restricters contend that the appropriate grounds are manifest to the required degree only at the domestic level. Extenders challenge such claims in one of two ways: by denying Restricters' accounts of the grounds of egalitarian justice; or by showing that the proffered ground is in fact manifest to the required degree at the global level (see, among others, Barry and Valentini, 2009; Abizadeh, 2007; Caney, 2011; Pevnick, 2008). The discussions in sections 2 and 3 sidestep this familiar script by eschewing claims about the grounds of egalitarian justice. Political competition is not a ground of egalitarian justice here; it is a causal condition for realizing a minimum demand of cosmopolitanism. Hence, the burden of proof that emerges from section 3 cannot be met by Extenders' standard efforts to show that the grounds of egalitarian justice have global scope. Additionally, my argument supplies a novel and rigorous account of the causal mechanisms underpinning the claim that a system of states can be an effective means for realizing cosmopolitan objectives. Hence, existing efforts to sustain global egalitarianism on pragmatic grounds will not do (e.g., Cabrera, 2004; Caney, 2006; Pogge, 2008).

\section{FROM COSMOPOLITANISM TO DEVELOPMENT}

Cosmopolitanism is a moral view that endorses the following commitment: all human beings enjoy equal status as the fundamental units of moral concern and, as such, they are owed equal concern and respect. Extenders argue that a cosmopolitan theory of justice - a specification of the principles of justice that follow from a basic commitment to moral cosmopolitanism - includes (at least) some broadly egalitarian distributive principles that apply globally. Restricters disagree. ${ }^{8}$ To further specify the relevant disagreement, notice that Restricters need not deny the global scope of non-egalitarian principles of justice. For example, Michael Blake (2011), David Miller (2007), and Richard Miller (2010) each support some sort of sufficientarian principle at the global level, which requires enabling individuals to avoid absolute deprivation. Restricters can also support non-individualist principles that require rough equality of some sort among states. One qualifies as a Restricter in the relevant sense if one denies global scope to distributive principles that limit the extent of interpersonal inequalities.

This disagreement notwithstanding, all cosmopolitans - Restricters and Extenders alike - accept the following claim: the demands of cosmopolitan justice are fulfilled

8 For my purposes here, a distributive principle is broadly egalitarian if it places principled limits on the type or extent of socioeconomic inequalities that are morally permitted among individual persons. 
only if persons everywhere live decent and worthwhile lives. ${ }^{9}$ To ease exposition in what follows, we can operationalize this conviction using the concept of development. Consider the fact that cosmopolitan justice is achieved only once all persons worldwide enjoy secure rights, decent levels of material welfare, and so forth. These outcomes are realized only if all persons live in political communities ${ }^{10}$ that achieve a minimum level of economic and political development. Below some threshold level, some persons must remain destitute and insecure, contrary to the demands of cosmopolitan justice. ${ }^{11}$

Measuring development levels is not a precise science, and there are several relevant metrics. Examples include the World Bank's ranking of countries according to average income levels, Freedom House's ranking of countries according to protection of individual civil and political rights, or the United Nations Development Programme's Human Development Index, which measures countries' performance in several key “indicator" areas, including life expectancy, educational attainment, health outcomes, and income (Freedom House, 2015; United Nations Development Programme, 2015; World Bank, 2015). The great overlap we find among different development rankings shows that a country's level of development according to one criterion is generally correlated with its achievement along other criteria (cf. Besley and Persson, 2011, ch. 1). There are exceptions: Equatorial Guinea and Saudi Arabia achieve high levels of average income but fare poorly on rights protection; the converse is true of Benin and India. But cosmopolitans do not typically think of these exceptions as successes from the standpoint of cosmopolitan justice. For practical purposes, the concept of development permits us to set aside Extenders' and Restricters' differences and speak of a shared cosmopolitan requirement. Cosmopolitan justice is realized when all individuals worldwide enjoy lives that look more like those of typical residents of middle class suburbs in Delhi or Sydney than those of typical residents of Goma (in eastern DR Congo) or Rio de Janeiro's favelas.

9 Restricters that endorse moral cosmopolitanism agree to the following two claims: (1) the principles of justice that follow from a commitment to cosmopolitanism are fulfilled only if each state is internally just; (2) a state is internally just only if all its members live decent and worthwhile lives. Together, these imply the claim in the main text. To deny global egalitarianism, a Restricter need only deny that cosmopolitan justice requires rough interpersonal equality at the global level or that members of a particular community have duties of justice to bring about rough equality between themselves and non-members. (Denying either of these is consistent with holding that members of a community have obligations to help non-members avoid absolute deprivation.)

10 I am being deliberately vague here to avoid assuming state-centrism.

11 Clearly, realizing a world wherein all persons live in communities that achieve a minimum level of development is not sufficient for global egalitarianism. But it is just as clearly necessary. 


\section{Cosmopolitanism and Competition}

\section{FROM DEVELOPMENT TO POLITICAL COMPETITION}

Some proportion of residents in underdeveloped regions are guaranteed to lack (some of) the requirements of a decent and worthwhile life. So, as a necessary first step, realizing cosmopolitan justice requires all political communities to achieve some threshold level of political and economic development.

We can exploit cross-country variation in development outcomes to tease out some of the key factors that explain why some communities develop successfully while others fail. ${ }^{12}$ While there is a lively debate on the details, there is an emerging consensus among social scientists that, broadly speaking, "institutions rule" when it comes to the determinants of development outcomes (Rodrik, Subramanian and Trebbi, 2004). ${ }^{13}$ Certain public goods such as the rule of law and government accountability constitute positive political development. These goods, as well as secure property rights, physical infrastructure, a healthy and educated labor force, and a stable macroeconomic environment (among other things), are also key determinants of economic development. But these public goods are costly to provide, in two senses. In the obvious sense, they cost money - governments must collect sufficient revenue to finance their provision. But, in the sense I will emphasize here, public goods provision imposes opportunity costs on public officials. In providing these public goods - that is, in implementing development-enhancing institutions and policies - political elites must forego opportunities for corruption, inefficient economic transfers, discretionary use of coercive force, and other forms of private gain. Why would a government provide the public goods needed for successful development given these costs? As social scientists have repeatedly affirmed, political leaders reliably use their political power to provide development-enhancing public goods insofar as there are institutional mechanisms in place to circumscribe their exercise of power and commit them to advancing their constituents' general interests (see, among others, Acemoglu and

12 To forestall the worry, note that I am not here vulnerable to Pogge's (2008) criticisms of "explanatory nationalism", the view that global development shortfalls are explained entirely by domestic causal factors. I appeal to country-level comparative analysis to expose important features that covary with development outcomes with the aim of exposing potential causal factors. I leave open the possibility that international factors play some role in explaining cross-country variation in development outcomes. In fact, exposure to certain global-level factors can emerge from a country-level comparative analysis as an important covariate. 13 Recent surveys include Acemoglu, Gallego and Robinson (2014); Engerman (2008); Haggard, MacIntyre and Tiede (2008); Nunn (2014). To be clear, the claim here is not that other factors - such as culture, geography, or social capital - do not matter for development outcomes. Other factors might help explain the development of institutions (see, e.g., Acemoglu, Johnson and Robinson, 2001; Easterly, Ritzen and Woolcock, 2006; Nunn, 2012). The claim, instead, is that these other factors do not matter for development independently; they affect development outcomes only in interaction with institutional context. 


\section{David Wiens}

Robinson, 2012; Besley and Persson, 2011; Bueno de Mesquita et al., 2003; Humphreys and Bates, 2005; North, 1981, 1990; Persson and Tabellini, 2000). ${ }^{14}$

This raises the question of how the required institutional mechanisms emerge: which factors induce their implementation? A predominant line of scholarship analyzes institutional origins and development within a social bargaining framework, in which political leaders negotiate with constituent groups over policy. Although the details differ across theoretical variants, the core idea is the same: political leaders accept institutional limits on their power as a means to make credible commitments to prospective supporters (cf. Acemoglu, 2003; Acemoglu and Robinson, 2006; Bates and Lien, 1985; Boix, 2003; Boix and Svolik, 2013; Levi, 1988; Myerson, 2008, 2011; Tilly, 1992; Weingast, 1997).

Political leaders typically require support from some subset of their constituents to resist challenges to their rule, be it as a source of revenue, electoral support, or military assistance to defeat a rival. To secure their support, leaders offer policy concessions to those whose support is necessary for retaining office. Without any mechanism to bind leaders to follow through on their promises, prospective supporters have little assurance that leaders will deliver as promised - they have little reason to regard their leaders' offers as credible. A lack of credibility is no problem if constituents have no other option but to support an incumbent leader - the leader has no need to commit to any concessions to induce support in such circumstances. But if constituents' alternatives to cooperating with an incumbent (e.g., placing their money in investments that evade taxation or confiscation; voting for a leadership challenger; mounting an armed rebellion) promise to be more valuable than the discounted value of the leader's offer, then constituents can credibly threaten to withhold their support from the leader. If the required supporters can credibly threaten to withhold critical support from a political leader, the leader must solve a commitment problem to attract the necessary support. To overcome this problem, leaders implement institutional mechanisms that constrain them to follow through on promised concessions as a means to signal the credibility of their offers.

This dynamic is argued to be quite general: When political leaders must solicit cooperation from constituents, they are induced to bargain over policy with prospective supporters. When those supporters can credibly threaten to withhold the required support, political leaders must give up some discretionary control over future policy decisions in exchange for support in the present. The logic of the explanation does not imply that democratic institutions must be in place to empower constituents to credibly withhold cooperation from political leaders. As the examples given above (and below) indicate,

14 Nothing said thus far implies that the relevant institutional mechanisms must be democratic in nature. More on this shortly. 


\section{Cosmopolitanism and Competition}

electoral support is not the only form of constituent support on which leaders might rely. Nor does it imply that leaders must signal a credible commitment to supporters by introducing specifically democratic institutions. Leaders might do just that, of course (Acemoglu and Robinson, 2006; Boix, 2003). But they need not. Under conducive circumstances, they might, instead, introduce institutional innovations that allow them to retain autocratic control while signaling a credible commitment to prospective supporters (Boix and Svolik, 2013; Svolik, 2012).

The foregoing discussion highlights the importance of bargaining between political leaders and their constituents - those they aspire to rule - as a determinant of the extent to which governments are responsive to constituents' general interests and, in turn, as a determinant of a community's development trajectory. A community is most likely to reliably experience stable development gains when the bargaining dynamic is such that the local ruler must credibly commit to providing development-enhancing public goods in exchange for support from constituents. When constituents have little bargaining leverage to constrain the ruler, the latter can rule without regard for constituents' general interest in higher levels of development.

Let me introduce two concepts as a means to impose some structure on the argument of this section. A government is broadly responsive to the extent that it advances constituents' general interests in response to constituents' actual or expected conduct. This notion has two core features. First, a government is broadly responsive to the extent that it selects policies that advance the interests of constituents generally and not just the interests of a small political and economic elite. Among other things, a responsive government accepts institutional limits on its exercise of power, is attentive to a broad and diverse range of interests, and provides public goods that lead to broadly distributed economic gains. In contrast, an unresponsive government represses political challenges and pursues the private interests of a ruling elite at the expense of its other constituents' interests. Second, a broadly responsive government advances constituents' interests because, given constituents' actual or anticipated conduct, doing so more effectively consolidates the leader's rule than failing to do so. This last feature is key. A government need not advance constituents' interests out of goodwill or public spiritedness to qualify as responsive (although it might be commendable for doing so). A government is responsive only insofar as it advances constituents' interests because it is constrained by constituents to do so. ${ }^{15}$ (I drop the "broad" qualification hereafter.)

15 This might seem counterintuitive to some: Surely, a government that pursues the public good without being constrained to do so is responsive, no? I concede that a public spirited government is attentive to constituents' interests. But it is responsiveness, not attentiveness, that matters here. An unconstrained 


\section{David Wiens}

Political competition is manifest to the extent that political leaders must contend for support from constituents to fend off challenges to their rule. Here, "support" refers to the different forms of loyalty or cooperation political leaders might require from constituents to sustain their rule. Elaborating my earlier examples, political leaders require fiscal support from constituents to the extent that they rely on constituents as a source of revenue to finance their efforts to retain power; they require political support from constituents to the extent that they must solicit constituents' allegiance during some leader selection procedure (e.g., in the form of votes during an election); leaders require military support from constituents to the extent that they require constituents' participation in efforts to rebuff military challenges to their rule, both internal (e.g., coups) and external (e.g., invasions). Insofar as leaders do not require constituent support to sustain their rule, political competition is absent.

Political leaders must contend for support to the extent that constituents have worthwhile alternatives to supporting their leader and can, thus, credibly withhold the required support. For instance, political leaders must contend for fiscal support to the extent that constituents can place their money in investments that evade taxation and confiscation or funnel money to a political challenger. When these are live options, political leaders must convince a sufficient number of constituents that providing them with fiscal support yields a worthwhile return (e.g., Levi, 1988; Tilly, 1992). Similarly for political or military support; in these cases, political leaders must convince a sufficient number of constituents that they are better off providing them with the required support than withholding that support (e.g., Acemoglu and Robinson, 2006; Bueno de Mesquita et al., 2003). Contending for support is key because it increases the likelihood that political leaders seeking to retain power are reliably responsive to their constituents' interests. When competition is sufficiently manifest, institutional and policy outcomes are more likely to reflect a bargain (tacit or explicit) among aspiring political leaders and their constituents. Consequently, a community's development gains are robust - they need not depend on a leader's continued good will. Competition is here opposed to political imposition, which occurs when political leaders are able to impose their institutional or policy preferences upon constituents with impunity, whatever the latter's preferences or interests.

With these concepts in hand, we can summarize the argument of this section.

government might advance constituents' general interests if it decides to, but this leaves constituents' fate subject to the arbitrary power of the government. Since we are interested in robust development gains, I use the narrower concept of responsiveness proposed here to exclude cases of arbitrary provision of public goods. 


\section{Cosmopolitanism and Competition}

(1) A political community is most likely to sustain a minimum level of development if institutional arrangements are in place to constrain its political leaders (those who aspire to wield political power in the community) to use their power to advance constituents' general interests (e.g., Acemoglu and Robinson, 2012; Besley and Persson, 2011; North, 1990);

(2) Political leaders are most likely to create and maintain the requisite institutional arrangements if (and to the extent that) they are responsive to a broad and diverse group of constituents (e.g., Besley and Persson, 2011; Bueno de Mesquita et al., 2003)

(3) Political leaders are most likely to be responsive to a broad and diverse set of constituents if (and to the extent that) an adequate level of political competition is sustained within a political community (e.g., Acemoglu and Robinson, 2006; Bates and Lien, 1985; Myerson, 2008; Tilly, 1992);

(4) Thus, a political community is most likely to sustain a minimum level of development if (and to the extent that) an adequate level of political competition is sustained within a political community.

Drawing in the conclusion of section 1:

(5) We can fulfill the demands of a cosmopolitan theory of justice only if all political communities sustain a minimum level of development;

(6) Thus, we are most likely to fulfill a necessary condition for cosmopolitan justice if (and to the extent that) an adequate level of political competition is sustained in all political communities.

From a basic commitment to moral cosmopolitanism, we have derived a criterion for evaluating alternative institutional schemes.

The competition criterion. - Take two institutional schemes, $S_{1}$ and $S_{2}$. Other things equal, $S_{1}$ is normatively superior to $S_{2}$ from a cosmopolitan moral perspective to the extent that $S_{1}$ would, if implemented, engender more widespread political competition in a greater number of political communities than $S_{2}$ would, if implemented.

Put differently, cosmopolitans should favor $S_{1}$ over $S_{2}$ to the extent that $S_{1}$ would, if implemented, provide a greater number of individuals with sufficient bargaining leverage 
vis-a-vis their political leaders than $S_{2}$ would, if implemented. Since Restricters and Extenders share a basic commitment to moral cosmopolitanism, Restricters and Extenders alike must endorse the competition criterion.

The competition criterion applies to the design of institutions at any level, from local to global. Although the key empirical premises are formulated by investigating the determinants of cross-country variation in development outcomes, these premises do not depend on taking modern nation-states as the relevant unit of analysis. Responsiveness and political competition are salient to development outcomes in any situation where political elites seek to accumulate power and subject others to their rule. The competition criterion applies not only to the design of domestic institutions, but to the design of interstate and suprastate institutions too. Barring exceptional moral virtue among global political leaders, we have every reason to think that executives of global institutions are most likely to reliably use their power to provide development-enhancing public goods and advance individuals' general interests in secure rights and material welfare insofar as they are constrained by institutional mechanisms to do so. ${ }^{16}$ Such institutions are most likely to emerge when global leaders must be responsive to a broad and diverse constituency. And global leaders are most likely to be responsive to a broad and diverse constituency to the extent that a broad and diverse group of individuals have bargaining leverage vis-a-vis aspiring global leaders; that is, insofar as there is a sufficient level of political competition at the global level.

\section{SETTLING THE SCOPE OF EGALITARIAN JUSTICE: ONE STEP FORWARD}

I have argued that a basic commitment to moral cosmopolitanism implies the competition criterion as a standard for normatively evaluating institutional schemes, including those that are responsible for global distributive outcomes. Since Extenders and Restricters share a commitment to moral cosmopolitanism, the competition criterion constitutes

16 For the purposes of institutional analysis, there are good reasons to assume that political leaders' choices are predominantly motivated by their own political survival. In the first place, we want to avoid institutional schemes that leave us vulnerable to exploitation by self-interested opportunists (Brennan and Buchanan, 1981). But the point here applies even if some leaders are committed altruists. Suppose our altruist's survival in office depends on satisfying the private interests of a powerful group of elites; failing to meet their demands, the altruist will be replaced by a more malleable leader. So either the altruist accedes to the elites' demands, diverting resources away from public goods; or she is replaced by someone else who diverts resources away from public goods. Thus, even if some global political leaders are committed altruists, it pays to consider the conditions under which political leaders are responsive to a broad and diverse constituency. 


\section{Cosmopolitanism and Competition}

common ground among those who otherwise disagree about the scope of egalitarian distributive principles. In the remainder of the paper, I explore the potential implications of this shared evaluative criterion for the scope of egalitarian distributive principles.

My investigation proceeds in two steps. In the first subsection, I explore the role of the state in facilitating and protecting the kind of political competition required to bolster the likelihood of achieving a minimum level of development. In light of the competition criterion, the evidence surveyed here yields a presumption in favor of retaining a privileged place for states within a just global institutional scheme. The pivotal claim is that we lack adequate reasons to think that suprastate political communities of the sort proposed by some Extenders can more effectively foster broad political competition than a system of states. While this first step might seem orthogonal to questions about the scope of egalitarian justice - after all, some Extenders concede a privileged place for states within a just institutional scheme - it sets the stage for an investigation of the empirical issues that bear directly on the scope of egalitarian principles. This occurs in the second subsection, where I consider the ways in which states' privileged status as spheres of competition might constrain the actions and institutions plausibly required to satisfy global egalitarian principles. The pivotal claim here is that cross-border redistributive schemes of the sort required to implement egalitarian principles globally jeopardize political competition within recipient states by undermining political leaders' need to contend for support from those they aspire to rule. To justify their position, Extenders must present credible evidence to the contrary. That is, to justify extending the scope of egalitarian principles to the global sphere, Extenders must show that institutional articulations of global egalitarian principles are not likely to compromise political competition within recipient states, thereby compromising a crucial condition for achieving cosmopolitan justice.

A caveat before I proceed. The discussion to follow cannot form a conclusive case against global egalitarianism. There are multiple criteria by which we should evaluate institutional schemes - the competition criterion is not the only one. On top of that, other evaluative criteria likely pull in conflicting directions. A conclusive analysis of the scope of egalitarian justice must, at a minimum, enumerate the set of appropriate evaluative criteria, establish their relative significance, and analyze the implications of each criterion for the scope of egalitarian justice.

My main aim is to show how the scope of egalitarian justice turns on a range of as-yet neglected empirical issues. Additionally, I use the competition criterion to develop a challenge to global egalitarianism as a means to establish the normative significance 
of this criterion. ${ }^{17}$ More generally, this section illustrates the complex ways in which the justification of normative principles (and not merely their realization) depends on detailed institutional analysis - in particular, on analyses of the conditions under which institutional schemes can be expected to effectively satisfy abstract normative principles.

3.1. From competition to a system of states The competition criterion pushes us to consider the issue of global institutional design. Consideration of this issue would be intractable if we were to consider in detail the innumerable ways we might design a global institutional scheme. To focus discussion, I'll evaluate two broadly defined alternatives against the competition criterion: a fundamentally international system of sovereign states and a fundamentally global system marked by a layer of authoritative suprastate institutions above the state. (For convenience, I'll call these "the system of states" and "the global system" respectively.) The main difference between these two alternatives concerns the primary locus of underived political authority. "Political authority" refers to the recognized capacity to set and enforce policy within a specified jurisdiction. Authority in this sense is "underived" when agents outside the relevant jurisdiction cannot legitimately veto its exercise. In a system of states, political authority ultimately resides with the state; any authority vested in international institutions is derivative. A system of states is consistent with policy interdependence among states; states need not be unaffected by the policies of other states, nor must they have complete policy autonomy. Crucially, the term "state" does not denote present states; "system of states" does not denote the present configuration of sovereign borders in our world. A system of states is a world in which there is a layer of political organization composed of multiple sovereign communities with non-overlapping territorially-defined jurisdictions, each of which claims underived authority to set policy within its jurisdiction (including policies to manage the internal effects of other states' policy choices ${ }^{18}$ ) and none of which are legitimately subordinated

17 I set aside reflection on the competition criterion's significance relative to other plausible evaluative criteria.

18 This is a crucial point. Some scholars claim that state sovereignty has been effectively undermined because increased economic and environmental independence limit states' policy autonomy to a high degree (e.g., Dietsch and Rixen, 2014; Held, 1995; Ronzoni, 2009, 2012). But sovereignty (even the so-called "positive" variety) does not require that states be able to choose policies as they would in the absence of interdependence (just as positive freedom does not require that individuals be able to choose as they would were the consequences of their choices unaffected by the actions of others). So long as states have competed for scarce resources, their policy discretion has been limited to some extent. In fact, it is consistent with a state's continuing sovereignty that it initiate interstate cooperation to effectively limit its future policy discretion as a means to limiting the negative effects of interdependence. A state retains its sovereignty insofar as it is free to exit the cooperative arrangement at its discretion (and, of course, bear the costs of doing so). Hence, 


\section{Cosmopolitanism and Competition}

to a higher authority. Such a system can admit cooperative interstate institutions, to be sure; but these interstate institutions are ultimately the agents of sovereign states rather than principals in their own right. In one scholar's words, they are "creature[s] and servant[s] of the states system" (Jackson, 2007, 149).

In a global system, some nontrivial measure of underived political authority resides with suprastate institutions. Suprastate institutions are principals rather than agents, understood as centers of underived political authority, constitutionally superior to or parallel with subglobal units. On at least some issues, suprastate agencies hold preeminent power and authority. If states exist, their sovereign prerogatives are sharply limited by these suprastate institutions in a way that is qualitatively distinct from the limits imposed on states by current international institutions. For example, states in a global system cannot free themselves at will from the authority of global institutions, unlike states in the present system of international institutions (subject to the consequences of doing so, of course). An institutional scheme need not look like a world state to qualify as a global system in the relevant sense (cf. Zürn, forthcoming). It is enough to qualify if underived political authority is "vertically dispersed" among political units of varying size that are arranged within a nested institutional structure, with the smallest units having limited jurisdiction and the largest unit(s) having global remit (Pogge, 1992). This is the most important contrast with a system of states, which largely concentrates underived political authority at a single level: the state.

At first blush, we might have little reason to be optimistic about states' general capacity to foster enough political competition to stimulate political and economic development gains. Examples of countries ruled by dictators run amok are numerous and widely known. In light of such cases, numerous theorists have lodged powerful objections to a system of sovereign states. Prevailing sovereignty norms grant unaccountable leaders important international rights, such as the right to sell off a territory's resources or to borrow money on the country's behalf. These rights support authoritarians' efforts to "free themselves from public accountability through repression and bribery", while also encouraging coups and civil wars (Wenar 2008, 13; cf. Pogge 2008). Further, the right of territorial integrity leaves "national governments... effectively free to control 'their' populations in whatever way they see fit"; perhaps predictably, "[m] any make extensive use of this freedom by torturing and murdering their domestic opponents, censoring informa-

sovereignty is eroded only if the norms of political independence and nonintervention are compromised (Philpott, 2001, 25-30). The policy constraints that arise from economic or environmental interdependence might be just as well conceived as the outcome of interactions among politically independent entities rather than an infringement of political independence. 


\section{David Wiens}

tion, suppressing and subverting democratic procedures, prohibiting immigration, and so forth" (Pogge, 2008, 188). The current system of sovereign states "empowers governments that engage in systematic violations of human rights"; insofar as we uphold a system of states marked by the current practice of sovereign recognition "without protest", we are "accomplice[s] to injustice" (Buchanan, 2004, 3). Put simply, it seems problematic at best that a system of states holds much promise for facilitating and protecting widespread political competition. We might naturally infer from states' dismal overall record that the competition criterion would lead us to prefer a scheme of accountable (perhaps democratic) suprastate institutions.

This is precisely the inference that some Extenders have made. From democratizing existing international institutions (Caney 2005, ch. 5; Moellendorf 2005) to more or less fundamentally restructuring relations of political authority at the global level (Cabrera, 2004; Held, 1995; Macdonald, 2008; Pogge, 1992), numerous Extenders have argued that a just global institutional scheme must include a layer of suprastate institutions with sufficient underived authority to circumscribe and check the activity of states (see also Buchanan, 2004; Gilabert, 2012; Gould, 2004). Echoing the sentiments of others, Caney argues that suprastate institutions are "needed both to provide a reliable and effective means of protecting people's basic interests... and also to provide a fair forum for determining which rules should govern the global economy" (2006, 734). Caney presents several reasons to support this claim (cf. Nili, 2013; Ronzoni, 2012) Preeminent among these are suprastate institutions' potential capacity to solve global collective action problems, assign responsibilities among global actors fairly, and provide a means for weaker states to hold powerful states accountable. With respect to the specific issues raised by the competition criterion, Caney also argues that suprastate institutions can enforce compliance with cosmopolitan principles and (if democratic) grant individuals greater influence over the content of important policies to which they will be subject. These are powerful reasons to think that a global scheme of suprastate institutions might better satisfy the competition criterion than anything resembling the current system of sovereign states. ${ }^{19}$

We should be cautious about moving too quickly from the claim that a system of states generally does a poor job of fostering political competition to the conclusion that a global system would do a better job. In the first place, the competition criterion only requires us to select the feasible institutional scheme that best fosters widespread competition. There is no guarantee that the best feasible institutions in this respect will do a commendable

19 Note the instrumental character of Caney's (and allies') reasoning here. As Caney puts it, "cosmopolitans are primarily committed to whatever institutions best serve human beings" (2005, 12, original emphasis). 


\section{Cosmopolitanism and Competition}

job of fostering competition relative to some (fanciful) ideal. Second, and relatedly, the conclusion that a global system is superior doesn't follow solely from the claim that a system of states does a lousy job of fostering competition. Proponents of a global system must also present a somewhat detailed account of: (1) the causal mechanisms that currently affect political competition, (2) the causal mechanisms potentially set in motion by a global system, and (3) the potential interactions between these two sets of causal mechanisms with respect to the promotion of political competition. Extenders have yet to offer any such account, for all their numerous and varied institutional proposals. ${ }^{20}$ In the absence of a credible model, we simply have no idea how a global system would fare with respect to the competition criterion or how it would compare to a system of states in that regard. ${ }^{21}$ At least we have some ideas (perhaps imperfect) about the conditions under which competition is facilitated within states and how we might expand the realization of those conditions within a system of states. Add to our uncertainty about how a global system would operate the grave risks of creating ultimately authoritative global agencies with sufficient power to enforce their rule (e.g., Kant, 1996; Rawls, 1999), and we have some presumptive reason to favor of a system of states with respect to the competition criterion.

A second, more pointed reply warns against making unfair comparisons. When Extenders propose that we replace a system of states with a global system, they typically compare a dysfunctional system of states with a more or less well-functioning global system. But this is an unfair comparison. If we are going to compare the two alternatives with respect to their fulfillment of the competition criterion, we must consider their respective performance under the same behavioral assumptions. More precisely, if we start with a global system as it would function assuming full compliance with normative principles, we must compare it to a system of states as it would function assuming full compliance; alternatively, if we start with a system of states assuming partial compliance, we must compare it to a global system as it is likely to emerge under partial compliance.

Suppose we want to know which institutional scheme would best satisfy the competition criterion in the ideal case. We then have a well-functioning global system, in which global political leaders are reasonably responsive to the interests of ordinary individuals and accept institutional limits on their exercise of political power. Consequently, global

20 Wiens (2013) elaborates this point, paying special attention to institutional proposals offered by Caney and Pogge.

21 There's also the difficulty of speculating credibly about how a counterfactual scenario that differs so markedly from our own would play out with respect to the dimensions of interest (competition, in this case). See James (2012, ch. 4); Risse (2012, ch. 16) for discussion on this point. 
political leaders reliably use their power to provide development-enhancing public goods and advance the general interests of ordinary persons. But, to be fair, this should be compared to a well-functioning system of states, in which state leaders are reasonably responsive and, as a result, reliably advance persons' general interests. If this is the correct comparison, then there's no reason to favor a global system (cf. Valentini, 2012, 78f). All our reasons to look beyond a system of states derive from its manifest dysfunctions.

The apt comparison for our purposes here is between the level and extent of competition we can reasonably expect to achieve within the dysfunctional system of states we have and the level and extent of competition we could achieve given the dysfunctions we should reasonably expect to emerge in any feasible global system. We know, from observing our world, that the level of competition manifest within states differs widely and that there are numerous states wherein competition is virtually non-existent and, consequently, state leaders are largely unresponsive to their citizens. Perhaps this leaves us pessimistic about the prospects for widespread competition within a system of states. ${ }^{22}$ The question is whether we can reasonably expect a global system to fare any better with respect to widespread competition, given the causal mechanisms that hinder competition (see the citations in section 2). Setting aside the worry (noted above) that Extenders have thus far failed to give us a credible model of how a global system would work, let me suggest some reasons for skepticism.

Since we lack any empirical evidence concerning the operation of a global system, we have to make inferences as best we can from what we know. We might start by trying to extrapolate from the operation of existing attempts to deepen international cooperation. This yields a dismal picture for a global system. Social scientists repeatedly affirm that international organizations tend to favor powerful special interest groups by design. International organizations "are born of politics. Powerful interests create international institutions to increase the welfare and stability of the founders" (Gartzke and Naoi, 2011, 594). From the flow of multilateral development aid to corrupt governments to "vote buying" at the United Nations, powerful special interest groups are able to use their organizational advantages (small enough to organize and act quickly, wealthy enough to possess bargaining leverage) to co-opt global and domestic political elites and influence international organizations' policies toward their private gain, sometimes at the expense of the general public interest. The fact that international organizations are typically designed to insulate decision makers from popular pressure and oversight only serves to enhance special interests' influence by marginalizing ordinary persons as

22 Although the widely-noted spread of democracy and decline in overall poverty rates at least suggests reasons to temper our pessimism here. I mention this only to set it aside. 


\section{Cosmopolitanism and Competition}

a potential counterweight to special interests. ${ }^{23}$ None of this is to say that international organizations cannot help to enhance governments' responsiveness to ordinary citizens (Keohane, Macedo and Moravscik, 2009). But the findings on this point pertain to international organizations' capacity to improve domestic governments' responsiveness to their citizens; the point Extenders need to establish is that a global system is capable of enhancing global political elites' responsiveness to ordinary persons.

A natural rejoinder here is that suprastate organizations within a just global institutional scheme are meant to be democratic, which would clearly improve competition and enhance global authorities' responsiveness to ordinary people's general interests. Since existing international organizations fall far short of being democratic, we cannot extrapolate from the operation of the status quo to the level and extent of competition we can reasonably expect within a feasible global system.

If this point is about the level and extent of competition we would find in an ideal global system, then it is beside the point - we are here trying to determine the level and extent of competition we can justifiably expect in any global system we are likely to establish taking the status quo as our starting point. The question, then, is whether we can reasonably expect to get from the status quo to the system of democratic suprastate organizations the objector has in mind. I submit that we have too little evidence to justify optimism. $^{24}$

If this rejoinder is instead about the level and extent of competition we would find in any feasible global system, it is unduly optimistic. One insight we can safely extrapolate from the status quo is that any transition to a global system - from the status quo to an institutional scheme featuring effectively authoritative suprastate organizations - will be carefully managed by global political and corporate elites. This is because any institutional reform will have important distributional effects, creating winners and losers (relative to the status quo) from the emerging suprastate institutional arrangements. Given these distributional consequences, powerful vested interests will seek to use their current position to channel reform efforts in directions that, at the very least, preserve their current socioeconomic position, if not increase their relative share of the gains from global social cooperation. As noted at the end of section 2, suprastate institutions that can effectively constrain global political authorities to advance ordinary people's general

23 Gartzke and Naoi (2011) survey some of the relevant issues.

24 But see Zürn (forthcoming). One shortcoming of Zürn's analysis relative to my purposes is that it neglects the likely consequences of feasible democratic global systems for broad political competition. Thus, while (e.g.) cosmopolitan democracy might be feasible (although I think Zürn's analysis on this is a little too optimistic), we are left with the question of how it fares with respect to the competition criterion. 
interests are likely to emerge insofar as those who would be responsible for implementing institutional reforms are responsive to a broad and diverse constituency. At present, though, this responsiveness condition doesn't hold, given that current international organizations are largely designed to insulate global policymakers from popular pressure. There is no counterweight to the influence of special interests at the level of global politics. Consequently, we have little reason to think that the institutional reforms undertaken during the crucial formative stages of a transition to a system of authoritative suprastate institutions will voluntarily seek to enhance global political competition.

The development of the European Union offers a cautionary tale here, contrary to the optimism of some Extenders (e.g., Cabrera, 2004; Pogge, 2008). For the most part, the development of EU institutions has been managed by European political and corporate elites. This fact is reflected in the constitution of EU institutions, several features of which "insulate the EU from political competition" (Follesdal and Hix, 2006, 552). ${ }^{25}$ Two of the EU's three political institutions, the European Commission and the Council of Ministers, are composed of political appointees and, thus, insulated from electoral review. This means that incumbent and prospective members need not contend for voters' support; they need only contend for the support of EU political elites. The only directly elected body, the European Parliament (EP), is the weakest of the three institutions. Although it has become increasingly powerful through a series of reforms, "it is not a major overstatement to claim that the electoral connection [between citizens and elected legislators] in the European Parliament is almost nonexistent!" (Hix and Høyland, 2013, 184). One key issue is that EP elections are contested by national parties and treated as midterm reviews of the incumbent national governments. Consequently, there is little incentive for EP legislators to formulate and present policy alternatives to the status quo EU agenda, which is set by the unelected Commission (Hix and Høyland, 2013). Put simply, EU institutions diminish rather than enhance contestation over the shape and direction of EU policy. Moreover, EU citizens persistently complain that EU institutions are too distant and their operation too opaque to give them any real influence over the policy process. It is little wonder, then, why EU citizens frequently allege that policy is made by elites for elites (Hix and Høyland, 2011). These worries about "democratic distance" - about the distance between global political authorities and ordinary people - are only exacerbated by the multiple layers of complex bureaucracy that would likely separate ordinary people from political executives in a system with global suprastate institutions. This complexity would further diminish the transparency 


\section{Cosmopolitanism and Competition}

of the global policy process and facilitate attempts on behalf of global elites to further conceal their dealings from ordinary people or mislead them about the content of global rules (Dahl, 2010; Kant, 1996).

One might reject the mainstream skepticism regarding the EU's democratic credentials by arguing that the EU is largely controlled by directly elected national governments, particularly through the Council of Ministers (ministers of national governments) and the European Council (nationally elected heads of state). Accordingly, the EU is subject to indirect electoral control (Moravscik, 2004). But this only serves my point — ordinary citizens' ability to influence and contest EU policy formation is best secured by the EU's remaining intergovernmental institutions. In other words, what political competition exists within the EU is largely due to the continued existence of states that foster internal competition. ${ }^{26}$ But this point does little to assuage worries regarding the negative effect of supranational institutions on political competition; nor is it inconsistent with the claim that we should prefer a system of states to a global system.

The discussion here falls far short of demonstrating that, according to the competition criterion, we have conclusive reason to favor a system of states to a global system of authoritative suprastate institutions. My argument remains open to numerous challenges. One aim of this section is to invite such challenges. Those who propose a fundamental departure from a system of states must do more than present us with optimistic speculations about (mere) possibilities for a global system. They must present us with credible evidence to support their optimism regarding the advantages of such a system from a cosmopolitan perspective. Until we have such evidence, the balance of considerations discussed in this section supports a presumption in favor of retaining a privileged role for states within a just global institutional scheme. To be clear, nothing I have said here supports the status quo; a cosmopolitan theory of justice might require that we markedly reform our current system of states. Consideration of the required reforms is beyond the scope of this paper. My only aim here has been to show that much work has yet to be done before Extenders can present a credible pragmatic case against retaining a (suitably reformed) system of states.

3.2. From states to the limits of egalitarianism The Extender's pragmatic challenge to statist restrictions on the scope of egalitarian justice claims that states have no place in a just institutional scheme because they frustrate our attempts to satisfy the practical requirements of cosmopolitanism. The last section argued that Extenders have yet to

26 Cf. Moravcsik: "Above all, the democratic legitimacy of the EU rests on the fact that national-states remain influential, democratic and technically competent” $(2004,363)$. 
vindicate this pragmatic challenge. Extenders might still press their principled challenge, insisting that state borders are irrelevant for fixing the scope of egalitarian principles of justice. At a glance, there is nothing inherent to a system of states that rules out the possibility that we bear duties to limit interpersonal inequalities at the global level. In this section, I argue that Extenders have yet to vindicate this principled challenge, showing how the competition criterion raises difficulties for Extenders' efforts to justify extending the scope of egalitarian justice to the global level.

Satisfying egalitarian principles globally will surely require us to reform international market institutions (e.g., World Trade Organization, International Monetary Fund) so that the gains from international economic cooperation are distributed more equitably than they are at present. But we have no reason to think that international market reforms are sufficient to satisfy egalitarian principles; the shortfalls are simply too great (James, 2012; Miller, 2010). Thus, it will not be possible to reliably satisfy egalitarian principles globally without establishing institutions to facilitate redistributive transfers - to supplement international market reforms to start, and to correct any remaining inegalitarian tendencies of the market on an ongoing basis. Examples of such institutions include Pogge's (2008, ch. 8) Global Resources Dividend proposal or Brock's (2009, ch. 5) various proposals for global tax and transfer schemes. Here, I focus solely on the ways in which nonmarket redistributive transfers potentially undermine competition and responsiveness within the domestic sphere, setting aside the issue of market reforms for another time. ${ }^{27}$ If cross-border redistributive transfers are required to satisfy global egalitarian principles but such transfers are likely to undermine competition and responsiveness within states, it follows that implementing global egalitarian principles jeopardizes the realization of cosmopolitan justice.

Global (nonmarket) redistributive schemes share a common feature: each of them proposes to transfer resources from higher income countries to lower income countries. From the perspective of lower income countries, these resources are "unearned", in the following sense: "state income is earned to the extent that the state has to put in effort in working with citizens in order to get its money" (Moore, 2001, 401, original emphasis). Moore highlights two key types of effort. The state must expend organizational effort when, to collect taxes, it builds an efficient bureaucratic apparatus that penetrates broadly and deeply into the population. The state must expend political effort when it invests money and human capital in "protecting and increasing the taxpaying capacity of its citizens" (Moore, 2001, 402); that is, in increasing citizens' capacity for economic

27 See James (2012) for a rich discussion of international market reforms. 


\section{Cosmopolitanism and Competition}

productivity. A government's income is unearned when it is received without having to invest much organizational or political effort vis-a-vis domestic constituents. Paradigm cases of unearned government income are foreign aid and revenues from the extraction of state-owned natural resources.

The negative effects of unearned state income on domestic governance - particularly where institutionalized mechanisms to induce state leaders to be responsive to citizens are weak - are well known to social scientists. One prominent strand of literature focuses on the relationship between taxation and governance. Unearned income frees governments from the need to raise revenues via taxation; without the need to elicit citizens' tax compliance, political leaders have few incentives to negotiate with citizens over policy (Karl, 1997; Ross, 2001). Further, low tax rates alleviate social pressures that might otherwise provoke demands for government accountability (Ross, 2004; Paler, 2013). Leaders who receive a large amount of unearned income relative to other sources thus have weak incentives to accept institutional limits on their exercise of political power. Without the need to collect taxes from a broad swath of the populace, leaders don't need to develop an efficient and disciplined bureaucracy, further weakening fiscal oversight. Another strand of literature highlights the ways in which unearned income facilitates patronage and coercion, which enable incumbent leaders to co-opt or suppress political challenges (Al-Ubaydli, 2012; Bueno de Mesquita and Smith, 2010a; Morrison, 2009; Smith, 2008; Wantchekon, 2002).

With respect to its consequences for governance outcomes, the key feature of unearned income is that it is unearned, that governments don't need to elicit the cooperation of citizens to receive it. Thus, we can abstract away from the source of the income and extrapolate insights from the social science scholarship on foreign aid and resource revenues to the potential effects of nonmarket transfers from global redistributive schemes. Like foreign aid and resource revenues, state leaders that receive a relatively high proportion of their income from redistributive transfers need not expend effort vis-a-vis their constituents to receive it. Put simply, global redistributive schemes are likely to undermine political leaders' need to contend for constituents' support. ${ }^{28}$ Where institutionalized accountability mechanisms are not already entrenched (as in many of the countries that would be net recipients of a redistributive scheme), the nonmarket transfers required to satisfy egalitarian principles are likely to diminish state leaders' reliance on constituents for fiscal support, thereby undermining political competition. In light of sections 1 and 2, this implies that global redistributive institutions risk undermining a necessary condition 
for inducing political leaders to advance their constituents' general interests and, hence, for realizing cosmopolitan justice. ${ }^{29}$

Extenders have an obvious reply here: their proposed redistributive schemes require that developing country leaders advance their constituents' general interests to receive their share. Granted. But this ignores the fact that those who hold the purse strings (donor countries and international financial organizations) have their own agendas and that they typically use their control over resources to pursue those agendas. If state leaders are not already constrained to advance their constituents' interests by domestic institutional mechanisms, then outside agencies' position yields bargaining strength, which likely moves recipient leaders to pursue donors' agenda, even to the detriment of their citizens (Alesina and Dollar, 2000; Bueno de Mesquita and Smith, 2009, 2010b; Stone, 2004). Sure enough, Extenders have in mind that outside authorities would use their bargaining influence to provoke recipient state leaders to fulfill the demands of cosmopolitan justice. But this will be most likely when these outside authorities are reliably responsive to the general interests of the recipient country's citizens, sometimes to the detriment of their own interests. Stable responsiveness, in turn, will be most likely when the global poor possess enough bargaining leverage vis-a-vis international redistributive institutions to constrain the latter to advance the general interests of the global poor (not to mention the heads of other states, who face constituencies with competing demands). The prospects of meeting this condition are problematic at best, as discussed in section 3.1.

Perhaps egalitarian redistributive institutions could bypass domestic governments altogether and give money and resources directly to individuals. This might even strengthen individuals' bargaining leverage by giving them something that their leaders want, thereby increasing the latter's incentive to negotiate with the former and potentially induce greater government responsiveness. ${ }^{30}$ This possibility is certainly worth exploring further; there

29 Extenders frequently points out how little redistributive schemes would cost rich countries. Given my point here, focusing on the cost to the rich countries obscures the cost to the residents of developing countries, measured in terms of the effect of unearned income on responsiveness. For example, using 2005 numbers, Pogge estimates that a $\$ 3$ dividend per barrel of extracted oil would raise around $\$ 90$ billion per year for redistribution, which is about 0.67 percent of global product. The increase in fuel prices is estimated to be about $\$ 0.07$ per gallon (Pogge, 2008, 211). This is pocket change for the rich. But $\$ 90$ billion in additional unearned income from Pogge's GRD approaches the net official development assistance given by OECD countries in 2011 , which was $\$ 133.5$ billion. This is only a start (and far from sufficient to satisfy egalitarian demands). Add to the GRD the revenues from a carbon tax ( $\$ 630$ billion/year) or a small currency transaction tax ( $\$ 300$ billion/year) (see Brock, 2009, 132-135), and suddenly unearned income from global redistributive schemes dwarfs foreign aid transfers, which are already large enough to jeopardize political competition and responsiveness within recipient countries.

30 Thanks to Christian Barry for raising this point. 


\section{Cosmopolitanism and Competition}

is a growing experimental literature that touts the positive development effects of transferring cash directly to poor people. ${ }^{31}$ Alas, extant studies have little evidentiary value regarding the likely consequences for political competition of implementing a crossborder scheme of individual-level transfers. ${ }^{32}$

The cash transfer programs studied in existing field experiments are implemented by domestic governments or nongovernmental organizations (NGOs). If a domestic government implements the cash transfer program under study, then this is evidence that the government is responsive to the interests of its poor constituents. The fact that such studies show that cash transfers can have positive welfare effects for recipients under conditions of responsive government tells us nothing about the likely welfare effects of cash transfer programs under conditions of unresponsive governments. But Extenders need a reasonable estimate of the latter if they are to be justified in claiming that a global scheme of cash transfers will not have perverse effects on political competition and, in turn, government responsiveness (let alone whether they can bolster competition and responsiveness). A similar worry holds if the cash transfer program under study is implemented by an NGO. Domestic governments can tightly constrain the activity of NGOs within their borders, making it difficult for these agencies to distribute resources directly to persons. As two cases in point, consider Sudan's expulsion of thirteen international nongovernmental humanitarian organizations in March 2008 in response to President Omar al-Bashir's indictment by the International Criminal Court (US State Department, 2011), or Egypt's refusal to register eight US nonprofit groups "on the grounds that their activities violated Egyptian sovereignty" (Kirkpatrick, 2012). Hence, the fact that NGOs are left alone to implement cash transfer programs is evidence that the domestic governments of the areas in which they operate are at least not hostile to the interests of their poor constituents. So these studies, too, have little to tell us about the likely consequences of extending a cross-border scheme of cash transfers to places in which political competition is lacking and governments are unresponsive. Additionally, unless we are going to walk up to people and place cash directly in their hands, direct transfers must be implemented through domestic institutions. (For example, international NGO GiveDirectly uses mobile banking technology to implement the transfer program.) So, for a cash transfer scheme to work, domestic governments must be responsive enough to provide the infrastructure

31 The Abdul Latif Jameel Poverty Action Lab at MIT keeps an up-to-date archive of field experiments on the effects of direct cash transfers; see http://www.povertyactionlab.org/search/apachesolr_search?view= grid\&filters=type:evaluation and filter the results by specifying "Cash transfer" as the policy issue.

32 See Cartwright and Hardie (2012) for an accessible discussion of the uses and abuses of randomized controlled trials. 


\section{David Wiens}

necessary to the scheme's success. One might also worry that, in countries where official corruption pervades and the rule of law is weak, political elites can use their power over domestic institutions (including the banking system) to appropriate some portion of the transfers for their own purposes.

Finally, we can gain insight on the likely governance effects of direct individuallevel redistributive transfers from the growing literature on migrant remittances, which are direct transfers from migrant workers to family members. Although remittances can increase government tax revenue (primarily through consumption taxes; see Singer, 2012), there is substantial evidence that, in countries with unresponsive domestic governments, remittances increase government corruption and institutional dysfunction and decrease public spending on health care and education. This is because remittances can ease popular demand for public services and thereby permit governments to divert resources toward patronage in an effort to consolidate support from a small group of elites (Abdih et al., 2012; Ahmed, 2012, 2013; Escribà-Folch, Meseguer and Wright, forthcoming). The decline in institutional quality undoubtedly undermines competition and responsiveness. The decrease in public services is also worrisome, for two reasons. First, public services foster competition by facilitating organization of mass political movements; thus, a decrease in public services mitigates citizens' ability to organize against an unresponsive government (Smith, 2008). Second, private individuals are rarely in a position to find adequate and stable health care or education in the absence of public investment in the required infrastructure. Thus, although the boost to household income provided by remittances might increase consumption of some important goods (e.g., food, shelter), this increased purchasing power will be insufficient to satisfy egalitarian requirements in the absence of sustained public investment in health care and education.

If, as the evidence surveyed in this section suggests, we should expect the nonmarket redistributive transfers required ${ }^{33}$ to satisfy egalitarian principles to compromise domestic political competition and, in turn, a country's level of political and economic development, then cosmopolitans should hesitate to endorse the global extension of egalitarian distributive principles. To be clear, nothing in this section shows that foreign aid or remittances or redistributive transfers do nothing to improve the lives of the global poor. (So it is beside the point to show that such transfers can do some good.) Nor have I shown that sufficientarian distributive principles do not extend globally; a cosmopolitan theory of justice might yet require that we do what we can to relieve absolute poverty (as many Restricters concede). Finally, I have not shown that we should reject proposals for

33 But certainly not sufficient, as I've already acknowledged. 


\section{Cosmopolitanism and Competition}

inequality-reducing market reforms. What I have shown is much more limited. Given that the competition criterion (defeasibly) favors retaining a privileged place for states in a global institutional scheme in an effort to bolster government responsiveness to ordinary persons' general interests, the discussion in this section suggests that we should limit large-scale cross-border redistributive transfers. Since ongoing global fulfillment of egalitarian principles is almost certainly impossible without an institutionalized cross-border redistributive transfer scheme, the discussion here suggests that cosmopolitan Extenders have yet to vindicate the global extension of egalitarian distributive principles.

\section{CONCLUSION}

The main points of this paper are as follows.

(1) Cosmopolitan justice is realized only if all persons worldwide live in political communities that achieve a minimum level of political and economic development (section 1).

(2) All persons worldwide are most likely to live in political communities that achieve a minimum level of development if we establish an institutional scheme that most effectively fosters widespread political competition (section 2).

(3) Extenders have yet to show that a system of authoritative global agencies more effectively fosters widespread political competition than a system of politically independent states (section 3.1).

(4) Extenders have yet to show that the cross-border nonmarket economic transfers required to satisfy egalitarian principles at the global level would not undermine political competition within states (section 3.2).

It follows from these points that Extenders have yet to show that implementing a mechanism required to satisfy egalitarian principles at the global level - cross-border redistributive transfers - would not undermine a crucial condition for realizing cosmopolitan justice. Thus, starting from cosmopolitan moral commitments, we can conclude that Extenders have yet to justify the global extension of egalitarian principles of distributive justice.

Clearly, I have not offered conclusive reasons to reject global egalitarianism. Instead, I have developed a novel criterion for evaluating global institutional schemes. Additionally, to illustrate the normative import of this criterion, I've used it to pose challenges for standard cosmopolitan arguments for global egalitarianism. I show that Extenders bear 
an as-yet neglected burden of proof that satisfying egalitarian principles globally would not jeopardize attempts to achieve the level of political and economic development required to fulfill the demands of cosmopolitan justice.

One might object that I have not raised any obstacles along the principled route to extending the scope of egalitarian justice - that section 3.2, like section 3.1, merely offers a pragmatic barrier to the implementation of global egalitarian principles. Thus, nothing I've said is relevant to the normative justification of egalitarian distributive principles with global scope. I conclude with a brief counterpoint.

A general normative principle is usually taken to be justified when it can be shown, from an appropriate standpoint of assessment, that the agents to whom the principle is addressed have sufficient reason to comply with its demands. On the approach I assume, normative justification is fundamentally intertwined with institutional analysis, which studies the background conditions under which various institutional schemes can be reasonably expected to engender normatively desirable states of affairs. So one cannot have sufficient reason to comply with a principle $P$ unless it can be shown that there is a mechanism that effectively satisfies $P$ under a set of background conditions that we can reasonably expect to bring about given the status quo. (It is not enough to find a mechanism that effectively satisfies $P$ under background conditions that we cannot reasonably expect to bring about.) Then, on the approach to justification I assume, one cannot have sufficient reason to comply with $P$ and $P$ is not justified. ${ }^{34}$

In this light, we can see how the main points of this paper imply that Extenders have yet to justify the global reach of egalitarian principles. In discrete steps, for clarity:

- A principle specifying duties of egalitarian justice with global scope is justified when it can be shown, from a cosmopolitan standpoint (which is assumed to be appropriate), that the relevant agents have sufficient reason to bring about broadly egalitarian distributive outcomes (including procedures).

- One cannot have sufficient reason to bring about egalitarian distributive outcomes at the global level unless it can be shown that there is a set of mechanisms that can effectively realize such outcomes under feasible background conditions.

- Points (1) and (2) (above) develop an important aspect of the cosmopolitan standpoint from which to assess the states of affairs we have normative reasons to realize.

34 See, e.g., Knight and Johnson (2011); Wiens (2015) for more extensive discussion of this approach to normative justification. 
- Point (3) restricts our attention to sets of background conditions involving an international system of states. This restriction is not imposed because all suprastate institutional schemes are shown to be infeasible. It is, instead, because Extenders have yet to show that a suprastate institutional scheme that fosters political competition more effectively than a system of states is feasible. Thus, Extenders have yet to show - from a cosmopolitan standpoint that attends to the competition criterion - that we have reasons to bring about a world in which there is a layer of ultimately authoritative suprastate institutions above the state.

- Finally, point (4) shows that Extenders have yet to show that a mechanism required (though not sufficient) to satisfy egalitarian principles in an international system of states - namely, a global scheme of nonmarket redistributive transfers - can effectively do so without compromising realization of a minimum demand of cosmopolitan justice.

Thus, given the approach to normative justification assumed here, Extenders have yet to show that we have sufficient reason to bring about global egalitarian outcomes and, thus, to comply with global egalitarian principles.

Extenders can meet this burden in one of several ways. First, they can counter the discussion in section 3.1 and offer compelling reasons to think that we should realize a system of authoritative suprastate institutions. If this is shown, then skepticism about the effectiveness of the redistributive mechanisms required to satisfy egalitarian principles in an international system of states is irrelevant. Second, Extenders can counter the discussion in section 3.2 and offer compelling reasons to think that a global scheme of nonmarket redistributive transfers need not compromise political competition and governments responsiveness in recipient states. If this is shown, then they will have given some good reasons to think that a mechanism required to satisfy egalitarian principles in a system of states can effectively do so without jeopardizing realization of a minimum demand of cosmopolitanism. This goes some way toward justifying global egalitarian principles. Lastly, Extenders can reject the approach to normative justification assumed here. But, to do so, they must say how a normative principle that specifies our duties to one another can be justified in the absence of any evidence that there exists a mechanism for its effective fulfillment under some plausibly feasible background conditions.

\section{REFERENCES}

Abdih, Yasser, Ralph Chami, Jihad Dagher and Peter Montiel. 2012. "Remittances and Institutions: Are Remittances a Curse?” World Development 40(4):657-666. 
Abizadeh, Arash. 2007. "Cooperation, Pervasive Impact, and Coercion: On the Scope (not Site) of Distributive Justice.” Philosophy \& Public Affairs 35(4):318-358.

Acemoglu, Daron. 2003. "Why Not a Political Coase Theorem? Social Conflict, Commitment, and Politics.” Journal of Comparative Economics 31:620-652.

Acemoglu, Daron, Francisco A. Gallego and James A. Robinson. 2014. "Institutions, Human Capital, and Development.” Annual Review of Economics 6:875-912.

Acemoglu, Daron and James A. Robinson. 2006. Economic Origins of Dictatorship and Democracy. New York: Cambridge University Press.

Acemoglu, Daron and James A. Robinson. 2012. Why Nations Fail: The Origins of Power, Prosperity, and Poverty. New York: Crown Business.

Acemoglu, Daron, Simon Johnson and James A. Robinson. 2001. "The Colonial Origins of Comparative Development: An Empirical Investigation." American Economic Review 91(5):1369-1401.

Ahmed, Faisal Z. 2012. "The Perils of Unearned Foreign Income: Aid, Remittances, and Government Survival.” American Political Science Review 106(1):146-165.

Ahmed, Faisal Z. 2013. "Remittances Deteriorate Governance." Review of Economics and Statistics. Doi: 10.1162/REST_a_00336.

Al-Ubaydli, Omar. 2012. "Natural Resources and the Tradeoff Between Authoritarianism and Development.” Journal of Economic Behavior and Organization 81(1):137-152.

Alesina, Alberto and David Dollar. 2000. "Who Gives Foreign Aid to Whom and Why?" Journal of Economic Growth 5:33-63.

Armstrong, Chris. 2014. "Global Justice between Minimalism and Egalitarianism." Political Theory 42(1):119-129.

Barry, Christian and Laura Valentini. 2009. "Egalitarian Challenges to Global Egalitarianism: A Critique.” Review of International Studies 35(3):485-512.

Bates, Robert H. and Da-Hsiang Donald Lien. 1985. "A Note on Taxation, Development, and Representative Government." Politics \& Society 14(1):53-70.

Beitz, Charles R. 1999. Political Theory and International Relations. 2nd ed. Princeton: Princeton University Press. 


\section{Cosmopolitanism and Competition}

Besley, Timothy and Torsten Persson. 2011. Pillars of Prosperity: The Political Economics of Development Clusters. Princeton and Oxford: Princeton University Press.

Blake, Michael. 2001. "Distributive Justice, State Coercion, and Autonomy." Philosophy \& Public Affairs 30(3):257-296.

Blake, Michael. 2011. “Coercion and Egalitarian Justice.” The Monist 94(4):555-570.

Blake, Michael. 2013. We Are All Cosmopolitans Now. In Cosmopolitanism Versus NonCosmopolitanism: Critiques, Defenses, Reconceptualizations, ed. Gillian Brock. New York: Oxford University Press.

Boix, Carles. 2003. Democracy and Redistribution. Cambridge: Cambridge University Press.

Boix, Carles and Milan Svolik. 2013. "The Foundations of Limited Authoritarian Government: Institutions, Commitment, and Power-Sharing in Dictatorships." Journal of Politics 75(2):300-316.

Brennan, Geoffrey and James Buchanan. 1981. "The Normative Purpose of Economic "Science": Rediscovery of an Eighteenth-Century Method." International Review of Law and Economics 1:155-166.

Brock, Gillian. 2009. Global Justice: A Cosmopolitan Account. New York: Oxford University Press.

Buchanan, Allen. 2004. Justice, Legitimacy, and Self-Determination: Moral Foundations for International Law. New York: Oxford University Press.

Bueno de Mesquita, Bruce and Alastair Smith. 2009. "A Political Economy of Aid." International Organization 63(2):309-340.

Bueno de Mesquita, Bruce and Alastair Smith. 2010a. "Leader Survival, Revolutions, and the Nature of Government Finance." American Journal of Political Science 54(4):936950.

Bueno de Mesquita, Bruce and Alastair Smith. 2010b. "The Pernicious Consequences of UN Security Council Membership.” Journal of Conflict Resolution 54(5):667-686.

Bueno de Mesquita, Bruce, Alastair Smith, Randolph M. Siverson and James D. Morrow. 2003. The Logic of Political Survival. Cambridge, MA: MIT Press. 
Cabrera, Luis. 2004. Political Theory of Global Justice: A Cosmoplitan Case for the World State. New York: Routledge.

Caney, Simon. 2005. Justice Beyond Borders: A Global Political Theory. New York: Oxford University Press.

Caney, Simon. 2006. "Cosmopolitan Justice and Institutional Design: An Egalitarian Liberal Conception of Global Governance.” Social Theory and Practice 32(4):725-756.

Caney, Simon. 2011. "Humanity, Associations, and Global Justice: In Defence of Humanity-Centred Cosmopolitan Egalitarianism.” The Monist 94(4):506-534.

Cartwright, Nancy and Jeremy Hardie. 2012. Evidence-Based Policy: A Practical Guide to Doing It Better. Oxford: Oxford University Press.

Dahl, Robert A. 2010. Can International Organizations Be Democratic? A Skeptic's View. In The Cosmopolitan Reader, ed. Garrett Wallace Brown and David Held. Cambridge and Malden, MA: Polity Press.

de Bres, Helena. 2011. “What's Special About the State?” Utilitas 23(3):140-160.

Dietsch, Peter and Thomas Rixen. 2014. "Tax Competition and Global Background Justice.” The Journal of Political Philosophy 22(2):150-177.

Easterly, William, Jozef Ritzen and Michael Woolcock. 2006. "Social Cohesion, Institutions, and Growth." Economics \& Politics 18(2):102-120.

Engerman, Stanley L. 2008. "Debating the Role of Institutions in Political and Economic Development: Theory, History, and Findings." Annual Review of Political Science 11:119-135.

Escribà-Folch, Abel, Covadonga Meseguer and Joseph Wright. forthcoming. "Remittances and Democratization." International Studies Quarterly .

Follesdal, Andreas and Simon Hix. 2006. "Why There is a Democratic Deficit in the EU: A Response to Majone and Moravcsik.” Journal of Common Market Studies 44(3):533-562.

Freedom House. 2015. "Freedom in the World." https://freedomhouse.org/report/ freedom-world/freedom-world-2015.

Gartzke, Erik and Megumi Naoi. 2011. "Multilateralism and Democracy: A Dissent Regarding Keohane, Macedo, and Moravcsik.” International Organization 65:589-598. 
Cosmopolitanism and Competition

Gilabert, Pablo. 2012. From Global Poverty to Global Equality. New York: Oxford University Press.

Goodin, Robert E. 1988. “What is So Special about Our Fellow Countrymen?” Ethics 98(4):663-686.

Gould, Carol. 2004. Globalizing Democracy and Human Rights. Cambridge: Cambridge University Press.

Haggard, Stephan M., Andrew MacIntyre and Lydia B. Tiede. 2008. "The Rule of Law and Economic Development.” Annual Review of Political Science 11:205-234.

Held, David. 1995. Democracy and the Global Order: From the Modern State to Cosmopolitan Governance. Stanford: Stanford University Press.

Hix, Simon and Bjørn Høyland. 2011. The Political System of the European Union. 3rd ed. New York: Palgrave Macmillan.

Hix, Simon and Bjørn Høyland. 2013. "Empowerment of the European Parliament." Annual Review of Political Science 16:171-189.

Humphreys, Macartan and Robert H. Bates. 2005. "Political Institutions and Economic Policies: Lessons From Africa.” British Journal of Political Science 35:403-428.

Jackson, Robert. 2007. Sovereignty: Evolution of an Idea. Malden, MA: Polity Press.

James, Aaron. 2012. Fairness in Practice: A Social Contract for a Global Economy. New York: Oxford University Press.

Kant, Immanuel. 1996. Toward Perpetual Peace. In Practical Philosophy, ed. Mary J. Gregor. Cambridge: Cambridge University Press pp. 311-352.

Karl, Terry Lynn. 1997. The Paradox of Plenty: Oil Booms and Petro-States. Berkeley and Los Angeles: University of California Press.

Keohane, Robert O., Stephen Macedo and Andrew Moravscik. 2009. "DemocracyEnhancing Multilateralism." International Organization 63:1-31.

Kirkpatrick, David D. 2012. "Egypt Rejects Registration Bids from 8 U.S. Nonprofit Groups.” The New York Times 23 April 2012. http://www.nytimes.com/2012/04/24/ world/middleeast/egypt-rejects-registration-bids-from-8-us-nonprofits.html.

Knight, Jack and James Johnson. 2011. The Priority of Democracy: Political Consequences of Pragmatism. Princeton: Princeton University Press. 
Levi, Margaret. 1988. Of Rule and Revenue. Berkeley and Los Angeles: University of California Press.

Macdonald, Terry. 2008. Global Stakeholder Democracy: Power and Representation Beyond Liberal States. Oxford: Oxford University Press.

Miller, David. 2007. National Responsibility and Global Justice. New York: Oxford University Press.

Miller, Richard W. 2010. Globalizing Justice: The Ethics of Poverty and Power. New York: Oxford University Press.

Moellendorf, Darrel. 2002. Cosmopolitan Justice. Boulder: Westview Press.

Moellendorf, Darrel. 2005. “The World Trade Organization and Egalitarian Justice.” Metaphilosophy 36(1/2):145-162.

Moore, Mick. 2001. "Political Underdevelopment: What Causes "Bad Governance"?" Public Management Review 3(3):385-418.

Moravscik, Andrew. 2004. "Is there a 'Democratic Deficit' in World Politics? A Framework for Analysis.” Government and Opposition 39(2):336-363.

Morrison, Kevin M. 2009. “Oil, Nontax Revenue, and the Redistributional Foundations of Regime Stability.” International Organization 63:107-138.

Myerson, Roger B. 2008. “The Autocrat's Credibility Problem and Foundations of the Constitutional State.” American Political Science Review 102(1):125-139.

Myerson, Roger B. 2011. “Toward a Theory of Leadership and State Building." PNAS 108:21297-21301.

Nili, Shmuel. 2013. "Who's Afraid of a World State? A Global Sovereign and the StatistCosmopolitan Debate." Critical Review of International Social and Political Philosophy $16: 1-23$.

North, Douglass C. 1981. Structure and Change in Economic History. New York and London: W. W. Norton \& Co.

North, Douglass C. 1990. Institutions, Institutional Change and Economic Performance. Cambridge: Cambridge University Press.

Nunn, Nathan. 2012. "Culture and the Historical Process." Economic History of Developing Regions 27(S1):S108-S126. 


\section{Cosmopolitanism and Competition}

Nunn, Nathan. 2014. Historical Development. In Handbook of Economic Growth, ed. P. Aghion and S. Darlauf. Vol. 2 North-Holland pp. 347-402.

Paler, Laura. 2013. "Keeping the Public Purse: An Experiment in Windfalls, Taxes, and the Incentives to Restrain Government." American Political Science Review 107(4):706-725.

Persson, Torsten and Guido Tabellini. 2000. Political Economics: Explaining Economic Policy. Cambridge, MA: MIT Press.

Pevnick, Ryan. 2008. "Political Coercion and the Scope of Distributive Justice." Political Studies 56(2):399-413.

Philpott, Daniel. 2001. Revolutions in Sovereignty: How Ideas Shaped Modern International Relations. Princeton: Princeton University Press.

Pogge, Thomas W. 1992. “Cosmopolitanism and Sovereignty.” Ethics 103(1):48-75.

Pogge, Thomas W. 2008. World Poverty and Human Rights. 2nd ed. Malden, MA: Polity Press.

Rawls, John. 1999. The Law of Peoples. Cambridge, MA: Harvard University Press.

Risse, Mathias. 2012. On Global Justice. Princeton: Princeton University Press.

Rodrik, Dani, Arvind Subramanian and Francesco Trebbi. 2004. "Institutions Rule: The Primacy of Institutions Over Geography and Integration in Economic Development." Journal of Economic Growth 9:131-165.

Ronzoni, Miriam. 2009. "The Global Order: A Case of Background Injustice? A PracticeDependent Account." Philosophy \& Public Affairs 37(3):229-256.

Ronzoni, Miriam. 2012. "Two Conceptions of State Sovereignty and Their Implications for Global Institutional Design." Critical Review of International Social and Political Philosophy 15(5):573-591.

Ronzoni, Miriam and Laura Valentini. forthcoming. Global Justice and the Role of the State: A Critical Survey. In Oxford Handbook of Global Justice, ed. Thom Brooks. Oxford: Oxford University Press.

Ross, Michael L. 2001. “Does Oil Hinder Democracy?” World Politics 53:325-361.

Ross, Michael L. 2004. “Does Taxation Lead to Representation?” British Journal of Political Science 34(2):229-249. 
Sangiovanni, Andrea. 2007. "Global Justice, Reciprocity, and the State." Philosophy \& Public Affairs 35(1):3-39.

Singer, David Andrew. 2012. "The Family Channel: Migrant Remittances and Government Finance.” MIT Political Science Working Paper No. 2012-23.

Smith, Alastair. 2008. “The Perils of Unearned Income.” The Journal of Politics 70(3):780793.

Stone, Randall W. 2004. “The Political Economy of IMF Lending in Africa." American Political Science Review 98(4):577-591.

Svolik, Milan. 2012. The Politics of Authoritarian Rule. New York: Cambridge University Press.

Tilly, Charles. 1992. Coercion, Capital, and European States, AD 990-1992. Revised ed. Malden, MA: Blackwell.

United Nations Development Programme. 2015. “The Human Development Index.” http://hdr.undp.org/en/content/human-development-index-hdi.

US State Department. 2011. "Background Note: Sudan.” http://www.state.gov/r/pa/ei/ bgn/5424.htm.

Valentini, Laura. 2012. Justice in a Globalized World: A Normative Framework. New York: Oxford University Press.

Wantchekon, Leonard. 2002. "Why do Resource Abundant Countries Have Authoritarian Governments?” Journal of African Finance and Economic Development 5(2):57-77.

Weingast, Barry R. 1997. "The Political Foundations of Democracy and the Rule of Law." American Political Science Review 91(2):245-263.

Wenar, Leif. 2008. "Property Rights and the Resource Curse.” Philosophy \& Public Affairs 36(1):2-32.

Wiens, David. 2013. "Demands of Justice, Feasible Alternatives, and the Need for Causal Analysis.” Ethical Theory \& Moral Practice 16(2):325-338.

Wiens, David. 2015. “Against Ideal Guidance.” Journal of Politics 77(2):433-446.

World Bank. 2015. “GDP per capita.” http://data.worldbank.org/indicator/NY.GDP.PCAP. CD. 


\section{Cosmopolitanism and Competition}

Ypi, Lea. 2012. Global Justice \& Avant-Garde Political Agency. New York: Oxford University Press.

Zürn, Michael. forthcoming. "Four Models of a Global Order with Cosmopolitan Intent: An Empirical Assessment.” The Journal of Political Philosophy. 